\title{
Pengaruh Green Product Terhadap Nilai Pelanggan dan Dampaknya pada Repurchase Intention \\ (Survey pada Konsumen Sariayu di Yogya Department Store Jalan Kepatihan Bandung)
}

\author{
Soesanty Maulany ${ }^{1}$, Agus Rahayu ${ }^{2}$ \\ Mahasiswa Magister Manajemen Bisnis \\ Sekolah Pasca Sarjana Universitas Pendidikan Indonesia
}

\begin{abstract}
Abstrak
Terjadinya persaingan yang semakin tinggi dalam industri kosmetik di Indonesia ditandai dengan banyaknya produk kosmetik berbagai merek baik lokal maupun kosmetik impor mengakibatkan penurunan penjualan produk PT. Martina Berto Tbk. Hal tersebut mengindikasikan bahwa terjadi masalah perilaku konsumen pada saat memutuskan menggunakan produk. Diperlukan upaya yang harus dilakukan perusahaan untuk dapat meningkatkan serta mempertahankan konsumen yaitu dengan menawarkan diferensiasi produk green product. Tujuan penelitian ini yaitu untuk mengetahui pengaruh green product terhadap nilai planggan dan dampaknya pada repurchase intention. Green product berpengaruh terhadap nilai pelanggan, dan nilai pelanggan berpengaruh terhadap repurchase intention. Metode yang digunakan adalah explanatory survey dengan teknik simple random sampling dengan jumlah sampel 175 responden. Teknik analisis data yang digunakan adalah regresi linier sederhana dengan alat bantu software komputer SPSS 16.0. Hasil yang diperoleh penelitian menyatakan bahwa green product memiliki pengaruh sebesar $4,1 \%$ terhadap nilai pelanggan, pengaruh nilai pelanggan terhadap repurchase intention sebear $25,1 \%$, sedangkan untuk green product tidak berpengaruh secara langsung terhadap repurchase intention.
\end{abstract}

Kata Kunci: Green Product, Nilai Pelanggan, Repurchase Intention

\section{PENDAHULUAN}

Setiap mahluk hidup memiliki kebutuhan yang harus dipenuhi. Menurut Kotler (2012:12) kebutuhan adalah syarat hidup dasar manusia, setiap orang memiliki kebutuhan yang berbeda dan dapat dipenuhi oleh barang dan jasa.

Saat ini kosmetik merupakan kebutuhan primer bagi wanita. Wanita senantiasa ingin terus terlihat menarik dalam setiap penampilannya, oleh karena itu wanita menggunakan berbagai macam kosmetik untuk mempercantik dirinya.

Berdasarkan data Kementrian Perindustrian bahwa saat ini perkembangan industri kosmetik Indonesia tergolong solid. Hal tersebut terlihat dari peningkatan penjualan kosmetik pada 2012 sebesar $14 \%$ menjadi $\operatorname{Rp} 9,76$ triliun dari sebelumnya $\operatorname{Rp} 8,5$ triliun dan pada tahun 2013 tumbuh hingga Rp 11,22 triliun naik 15\% dibandingkan tahun 2012 dan diprediksikan akan terus meningkat pada setiap tahunnya.

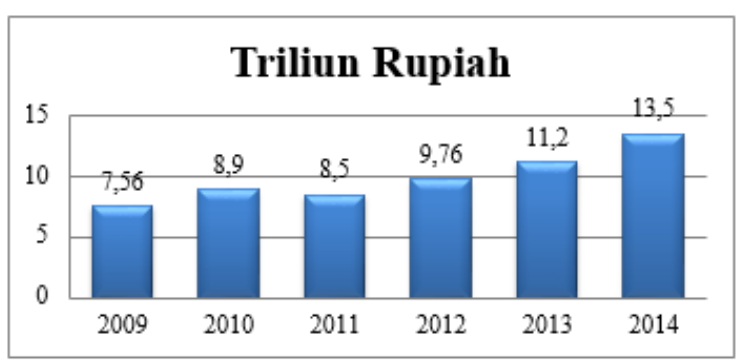

Sumber: http://indonesianconsume.blogspot.com/ dan majalah SWA

GAMBAR 1.1

\section{TINGKAT PENJUALAN KOSMETIK INDONESIA}

Kenaikan pasar kosmetik nasional Indonesia juga dipengaruhi oleh meningkatnya pertumbuhan masyarakat kelas menengah.

Persaingan yang ketat dalam industri kosmetik ditandai dengan banyaknya merek yang ditawarkan untuk pasar ini. Tabel 1.1 daftar berbagai merek kosmetik dari perusahaan lokal yang ditawarkan di Indonesia. 


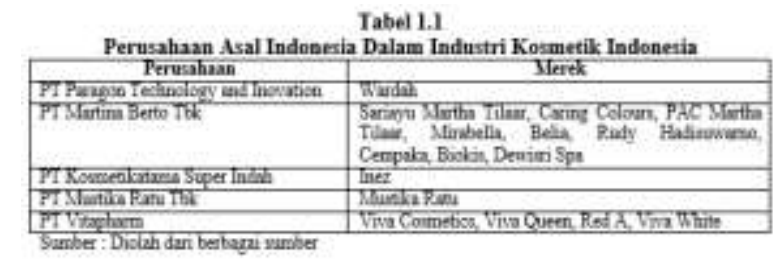

Tabel 1.1. menunjukkan 5 besar perusahaan kosmetik lokal yang bersaing menawarkan produknya di Indonesia. PT Martina Berto Tbk sebagai perusahaan utama dan tertua dalam industri kosmetik nasional Indonesia yang memiliki berbagai merek untuk produk kosmetiknya seperti Sariayu, Caring Colours dan PAC, Mirabella, Belia, Cempaka, Rudy Hadisuwarno, Biokos dan Dewisri Spa yang tergabung dalam Martha Tilaar Group. PT Martina Berto Tbk harus melakukan berbagai strategi untuk tetap bertahan dan bersaing dalam industri kosmetik. Bermunculannya produk kosmetik dari pesaing dapat merebut pasar yang selama ini telah dikuasai oleh Martha Tilaar Group.

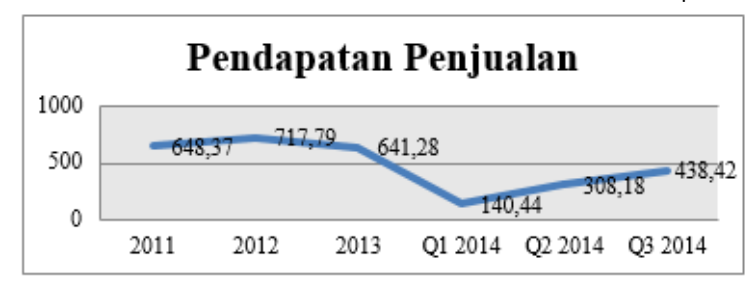

Sumber: www.infovesta.com dan annual report MBTO

GAMBAR 1.2

TINGKAT PENJUALAN PT MARTINA BERTO

Gambar 1.2 menunjukkan tingkat penjualan pada tahun 2013, pendapatan perusahaan PT Martina Berto Tbk mengalami penurunan pendapatan 10,66\% menjadi Rp 641,28 miliar dibandingkan dengan penjualan tahun 2012 yang mencapai Rp 717,79 miliar (www.infovesta.com). Penjualan pada Q1 2014 sebesar Rp 140,44 miliar lebih rendah dibandingkan dengan Q1 2013 sebesar Rp 166,85 miliar. Penurunan penjualan juga terjadi pada Q2 dan Q3 2014 yaitu masing-masing sebesar Rp 308,18 miliar dan Rp 438,42 miliar dibandingkan dengan Q2 2013 yang mencapai Rp 337,41 miliar dan Q3 2013 dengan penjualan Rp 486,22 miliar.

Masalah minat beli ulang konsumen kosmetik Sariayu diperkuat oleh Tabel 1.2 pembelian merek kosmetik dimasa yang akan datang dari konsumen Sariayu Yogya Kepatihan Bandung. Tabel 1.2 menunjukkan bahwa minat konsumen untuk membeli kembali kosmetik Sariayu pada pembelian selanjutnya adalah sebesar 20\%, masih berada dibawah minat beli Wardah dan Viva masing-masing sebesar 36,67\% dan $26,67 \%$ dan ini perlu menjadi perhatian bagi Sariayu.

TABEL 1.2

PEMBELIAN MEREK KOSMETIK DIMASA YANG AKAN DATANG

\begin{tabular}{|c|c|c|}
\hline Merek & Jumlah & Persentase \\
\hline \begin{tabular}{|l|} 
Sariayu \\
\end{tabular} & 6 & $20 \%$ \\
\hline \begin{tabular}{|l|} 
Viva \\
\end{tabular} & 8 & $26,67 \%$ \\
\hline \begin{tabular}{|l|} 
Wardah \\
\end{tabular} & 11 & $36,67 \%$ \\
\hline Mustikaratu & 5 & $16,67 \%$ \\
\hline Total & 30 & $100 \%$ \\
\hline
\end{tabular}

Ketika konsumen memutuskan untuk melakukan pembelian baik itu pembelian pertama kali ataupun pembelian ulang, ada beberapa hal yang dipertimbangkan oleh konsumen.

TABEL 1.3

FAKTOR YANG DIPERTIMBANGKAN KONSUMEN DALAM MELAKUKAN PEMBELIAN ULANG KOSMETIK

\begin{tabular}{|l|c|c|}
\hline \multicolumn{1}{|c|}{$\begin{array}{c}\text { Pertimbangan } \\
\text { Konsumen }\end{array}$} & Jumlah & Persentase \\
\hline $\begin{array}{l}\text { Green Product (Berbahan } \\
\text { Alami) }\end{array}$ & 16 & $53,3 \%$ \\
\hline Harga & 8 & $26,7 \%$ \\
\hline Iklan & 4 & $13,3 \%$ \\
\hline Kemasan & 2 & $6,7 \%$ \\
\hline Total & 30 & $100 \%$ \\
\hline
\end{tabular}

Sumber: Prapenelitian Maret 2015

Tabel 1.3 menunjukkan bahwa green product merupakan faktor terbesar yang mempengaruhi konsumen dalam melakukan minat pembelian ulang.

Sejak awal didirikan inovasi merupakan suatu hal yang harus dilakukan PT Martina Berto, terbukti dengan terbentuknya Martha Tilaar Innovation Center (MTIC). Upaya tersebut menghasilkan prestasi yang baik untuk perusahaan, yaitu menjadi Top 10 Outstanding Corporate Innovator Indonesia 2015 versi majalah SWA (SWA06 XXXI, 19 Maret-1 April 2015) seperti pada tabel 1.4 berikut.

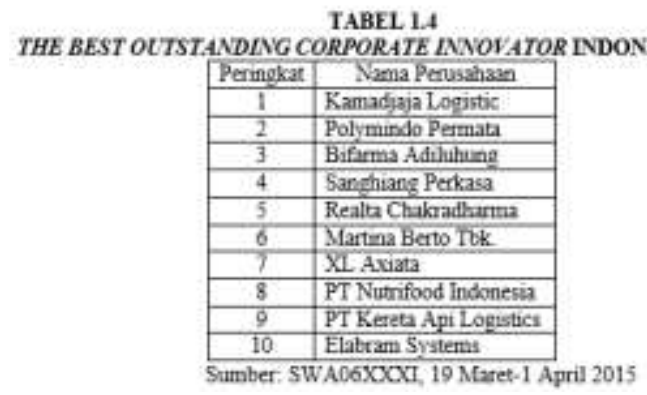

Martina Berto melakukan inovasi melalui green marketing dengan mengeluarkan koleksi rangkaian warna rias dengan tema berbeda setiap tahunnya.

Inovasi tersebut dilakukan oleh PT Martina Berto untuk memenuhi kebutuhan konsumen yang menginginkan value for money product di saat inflasi 
terjadi (Majalah Marketeers, Februari 2015). Berikut tabel 1.5 implementasi green product yang dilakukan Sariayu.

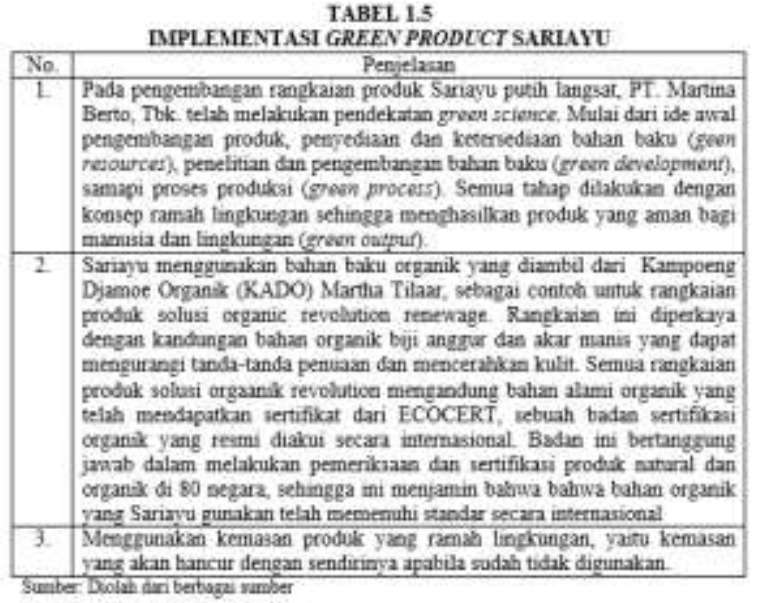

Nilai pelanggan merupakan indikator yang tepat untuk mengukur loyalitas pelanggan. Pelanggan yang merasakan nilai positif terhadap produk yang dikonsumsi makan akan merasakan kepuasan, sehingga nantinya akan melakukan pembelian kembali terhadap produk yang sama.

Berdasarkan fenomena yang telah diuraikan, maka dilakukan penelitian terhadap minat pembelian ulang. Persentase minat beli ulang terhadap produk kosmetik Sariayu berdasarkan hasil prapenelitian menunjukkan bahwa tidak banyak konsumen yang akan melakukan pembelian kembali terhadap kosmetik Sariayu. Green product sebagai salah satu faktor pertimbangan konsumen untuk memutuskan pembelian juga mempengaruhi nilai yang dirasakan pelanggan. green product dirasakan konsumen akan memberikan kualitas lebih dan dapat memenuhi kebutuhan dan keinginan konsumen.

Melihat betapa pentingnya sebuah perusahaan menerapkan strategi pemasaran dalam hal ini melakukan inovasi green product untuk dapat bersaing dan untuk meningkatkan minat pembelian kembali yang pada akhirnya akan meningkatkan penjualan produk tersebut serta untuk mengetahui faktor apa saja yang sangat berpengaruh terhadap penurunan penjualan PT Martina Berto dengan meninjau Sariayu Martha Tilaar sebagai brand yang paling diminati konsumen dan paling berkontribusi dalam total penjualan PT Martina Berto, maka penulis akan melakukan penelitian tentang minat pembelian ulang konsumen terhadap produk Sariayu.

\section{KERANGKA PENELITIAN \& HIPOTESIS}

Setiap perusahaan memiliki tujuan utama yang harus dicapai, upaya yang dilakukan dalam mencapai tujuan tersebut adalah dengan menciptakan produk yang dapat memenuhi kebutuhan serta keinginan konsumen. Kegiatan pemasaran dilakukan untuk mencapai tujuan perusahaan tersebut.

Definisi marketing menurut Kotler dan Armstrong (2012:29) "Marketing as the process by which companies create value for customers and build strong customers relationships in order to capture value from customers in return". Artinya "Pemasaran sebagai proses dimana perusahaan menciptakan nilai bagi pelanggan dan membangun hubungan yang kuat dengan pelanggan untuk menangkap nilai dari pelanggan sebagai imbalan".

Persaingan yang semakin ketat membuat perusahaan harus mampu untuk dapat terus bersaing dan mempertahankan serta terus mengembangkan pasar. Salah satu cara yang dapat dilakukan perusahaan adalah dengan menciptakan inovasi, baik inovasi pemasaran maupun inovasi produk. Perubahan keadaan pasar membuat terjadinya perubahan konsep pemasaran. Berikut adalah evolusi konsep pemasaran yang dikemukakan oleh Kotler dan Keller (2012:40):

1. Konsep Produksi

2. Konsep Produk

3. Konsep Penjualan

4. Konsep Pemasaran

5. Konsep Pemasaran Holistik

Kegiatan pemasaran akan berjalan dengan baik jika dilakukan berdasarkan konsep pemasaran holistik. Menurut Kotler dan Keller (2012:41) pemasaran holistik adalah suatu pendekatan yang berusaha menyadari dan mendamaikan ruang lingkup dan kompleksitas aktivitas pemasaran. Selanjutnya Kotler dan Keller mengemukakan empat komponen luas yang menjadi ciri dari pemasaran holistik, yaitu: pemasaran hubungan (Relationship Marketing), pemasaran terintegrasi (Integrated Marketing), pemasaran 
internal (Internal Marketing) dan pemasaran kinerja (Performance Marketing).

Dalam konsep pemasaran holistik juga mencakup performance marketing, kinerja pemasaran tidak hanya dilihat dari ukuran pendapatan penjualan, kepuasan pelanggan, kualitas produk, namun lebih luas yaitu mengenai hukum, etika, sosial serta lingkungan (Kotler dan Keller, 2012:44).

Semakin meningkatnya kesadaran konsumen akan lingkungan membuat konsumen menjadi green lifestyle, juga regulasi pemerintah mengenai lingkungan hidup dengan berdasar kepada peraturan Undang-Undang Pengelolaan Lingkungan Hidup no 23 tahun 1997, serta peraturan Pemerintah Republik Indonesia no 4 tahun 2001 tentang pengendalian kerusakan lingkungan hidup dan juga regulasi mengenai penerapan ISO 1400 mengenai sistem manajemen lingkungan dan ISO 14020 mengenai ecolabeling membuat perusahaan berupaya melakukan kegiatan usahanya dengan memperhatikan lingkungan, termasuk dengan melaksanakan green marketing, yaitu dengan menciptakan produk ramah lingkungan (green product).

Green product menurut Maheswari (2014), green product is products should be readily available for purchase and include those supplied by companies with a reputation for reducing environmental impacts from their manufacturing processes. Green product dapat diidentifikasi dengan dimensi berikut Maria (2010:471):

1. Energy based product

Melakukan efisiensi energi dan juga menggunakan energi yang dapat terbaharui.

2. Material-driven product

Efisiensi penggunaan bahan baku, dan menggunakan bahan-bahan reuse, recycle dan renewable.

3. Pollution-prevention product

Mengurangi produksi limbah dan polusi, dan mencegah pencemaran atau polusi.

4. Packaging

Menggunakan kemasan ramah lingkungan, berbahan dasar material daur ulang dan kemasan dapat didaur ulang.

Menciptakan green product adalah termasuk upaya perusahaan dalam memenuhi kebutuhan dan keinginan pelanggan. Pemasaran akan berhasil jika dapat memberikan nilai serta kepuasan bagi pelanggan.

Menurut Don Peppers dan Martha Rogers dalam Kotler dan Keller (2009:134) satu-satunya nilai yang dapat diciptakan perusahaan adalah nilai yang berasal dari pelanggan, itu adalah semua nilai yang perusahaan miliki saat ini dan nilai yang perusahaan miliki dimasa depan. Suatu bisnis dikatakan sukses ju]ika berhasil mendapatkan, mempertahankan, dan menumbuhkan pelanggan. Pelanggan merupakan satu-satunya alasan perusahaan membangun pabrik, mempekerjakan karyawan, ,enjadwalkan rapat, membuat jalur serat optik atau melibatkan diri dalam aktivitas bisnis apapun. Tanpa pelanggan anda tidak mempunyai bisnis.

Nilai pelanggan dapat diukur dengan menggunakan dimensi yang dikemukakan oleh Robinette dan Claire dalam Ratih Hurriyati $(2005,123)$ mengemukakan bahwa dimensi nilai pelanggan terdiri dari:

1. Rational value: product and price.

2. Emotional value: equity value, experience value dan energy value.

Ketika perusahaan dapat menciptakan nilai pelanggan yang baik dan kepuasan yang dirasakan pelanggan, maka akan tercipta loyalitas pelanggan. Repurchase intention merupakan salah satu indikator dari loyalitas. Menurut Teunter (2002:75) repeat purchasing indicates that a consumer's future probability of buying a brand currently purchased.

Minat beli ulang dapat diukur menggunakan tiga indikator yang dikembangkan oleh Teunter (2002:75), meliputi:

1. Intensitas pembelian

2. Kuantitas pembelian

3. Minat meneruskan pembelian ulang

Berdasarkan kerangka pemasaran tersebut, berikut disajikan paradigma penelitian dalam penelitian ini. 


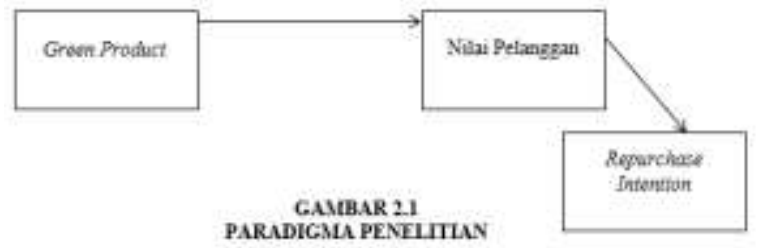

Hipotesis Penelitian

Hipotesis dalam penelitian ini adalah sebagai berikut:

1. Green Product berpengaruh terhadap Nilai Pelanggan.

2. Nilai Pelanggan berpengaruh terhadap Repurchase Intention.

3. Green Product berpengaruh terhadap Repurchase Intention.

\section{METODE PENELITIAN}

Penelitian mengenai pengaruh Green Product terhadap Nilai Pelanggan dan dampaknya kepada Repurchase Intention (Survey terhadap konsumen Sariayu Martha Tilaar Yogya Department Store J.Kepatihan Bandung) dengan menggunakan pendekatan manajemen pemasaran.

Variabel independen (X) pada penelitian ini adalah green product dengan menggunakan indikator energy based product, material-driven product, pollution prevention product, dan Packaging. Nilai Pelanggan sebagai variabel intervening (Y) menggunakan dua indikator, yaitu rational value dan emotional value. Kemudian repurchase intention sebagai variabel dependen (Z) yang diwakili oleh indikator minat transaksional, minat preferensial, dan minat eksploratif.

Objek penelitian ini adalah tanggapan konsumen produk Sariayu Martha Tilaar mengenai kesadaran konsuumen terhadap green product dan repurchase intention melalui nilai pelnggan, sedangkan yang dijadikan subjek penelitian adalah konsumen Sariayu Martha Tilaar di Yogya Department Store JI.Kepatihan Bandung.

Metode penelitian yang digunakan dalam penelitian ini adalah metode deskriptif dan verifikatif. Populasi dalam penelitian ini adalah seluruh konsumen yang membeli produk Sariayu Martha Tilaar di Yogya
Kepatihan Bandung dengan kriteria pernah membeli produk Sariayu Martha Tilaar lebih dari satu kali atau yang terdaftar sebagai member. Yogya Kepatihan Bandung dipilih karena lokasi yang berada pada pusat kota Bandung dan banyak masyarakat Bandung yang berbelanja ke tempat tersebut. Berdasarkan hasil wawancara dengan SPG counter Martha Tilaar Yogya Kepatihan, didapatkan bahwa terdapat sebanyak \pm 300 pelanggan yang datang ke counter tersebut selama satu bulan terakhir yaitu Maret 2015.

Hasil dari perhitungan dengan menggunakan rumus Slovin menyatakan sampel minimal dalam penelitian ini adalah sebanyak 171,4. Untuk memudahkan penelitian maka jumlah sampel ditetapkan sebanyak 175 orang. Jumlah responden sebanyak 175 orang tersebut dianggap sudah representatif karena sudah lebih dari batas minimal sampel.

Untuk menentukan sampel yang akan digunakan dalam penelitian ini digunakan teknik Probability Sampling dan secara khusus menggunkan simple Random Sampling. Skala pengukuran yang digunakan dalam penelitian ini adalah skala Likert. Teknik data yang digunakan dalam penelitian ini adalah regresi linier sederhana dan analisis korelasi.

\section{HASIL DAN PEMBAHASAN}

\section{Pengaruh Green Product Terhadap Nilai Pelanggan}

a. Uji Normalitas

Untuk menguji normalitas data, penelitian ini menggunakan Normal Probability Plot seperti pada gambar 4.1 berikut.
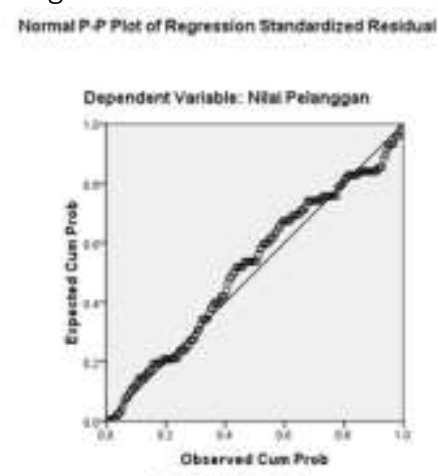

GAMBBAR 4.]

DIAGRAM GARIS NORMAL P-PLOT GREEN PRODUCT TERHADAP NILAI PELANGGAN PADA PENGGUNA SARIAYU DI YOGYA KEPATIHAN BANDUNG 
Berdasarkan Gambar 4.1 dapat disimpulkan bahwa model regresi yang diperoleh berdistribusi normal, dimana titik-titik sebaran data mengikuti garis lurus dan menyebar disekitar garis diagonal tersebut.

b. Uji Regresi Linier Sederhana

Regresi digunakan untuk mengetahui seberapa besar pengaruh green product terhadap nilai pelanggan, output ANOVA terdapat pada tabel 4.1

TABEL 4.1

OUTPUT ANOVA GREEN PRODUCT TERHADAP NILAI PELANGGAN

\begin{tabular}{|c|c|c|c|c|c|c|}
\hline \multicolumn{2}{|c|}{ Sindal } & $\operatorname{sen}$ of forores & $\ddot{q}$ & Men Souxe & 7 & 트 \\
\hline \multirow[t]{3}{*}{ i } & Escention & 3E. 165 & & 31.165 & 7374 & 507 \\
\hline & Ronital & $1904 \times 6$ & 123 & 11.007 & & \\
\hline & Traal & $1955, \pi$ & $1+4$ & & & \\
\hline
\end{tabular}

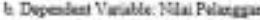

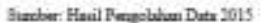

Berdasarkan Tabel 4.19 ANOVA, dapat diketahui besar $F$ hitung adalah 7,374 sedangkan $F$ tabel adalah 3,048, karena nilai

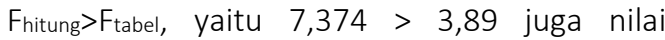
signifikansi sebesar 0,007<0,05 (taraf signifikansi 5\%) maka dapat disimpulkan Ho ditolak, yang artinya terdapat hubungan linier antara green product dengan nilai pelanggan.

TABEL 4.2

OUTPUT KOEFISIEN REGRESI GREEN PRODCCT TERHADAP NII AI PELANGGAN

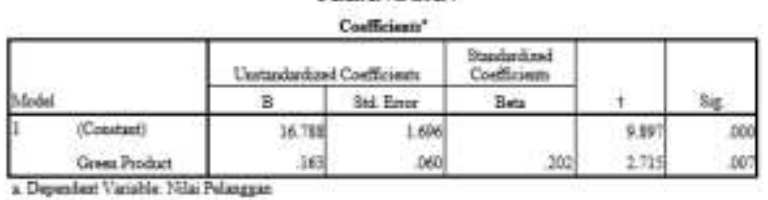

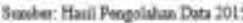

Berdasarkan persamaan tersebut uji regresi linier sederhana dapat dijelaskan sebagai berikut:

1. Koefisien konstanta sebesar 16,788 menunjukkan apabila green product bernilai 0 (nol) maka nilai pelanggan bernilai 16,788.

2. Setiap peningkatan skor sebesar satu satuan green product, maka akan berdampak pada kenaikan nilai pelanggan sebesar 0,163.

Berdasarkan tabel 4.2 juga dapat diketahui besarnya t-hitung yaitu sebesar 2,715 sedangkan besarnya t-tabel 1,97 atau t-hitung > t-tabel yaitu 2,715>1,97 maka dapat disimpulkan Ho ditolak, artinya ada hubungan linier antara green product dengan nilai pelanggan dengan tingkat signifikansi sebesar 0,007 yang lebih kecil dari taraf signifikansi 0,05 (5\%).

c. Analisis Koefisien Korelasi

Untuk mengetahui derajat hubungan anatara green product dengan nilai pelanggan dan untuk mengetahui arah serta kuatnya hubungan antara kedua variabel tersebut, maka digunakan tabel 4.3 koefisien korelasi seperti berikut:

\section{TABEL 4.3}

OUTPUT KOEFISIEN KOREI ASI GREEN PRODLCT TERHADAP NILAI PELANGGAN

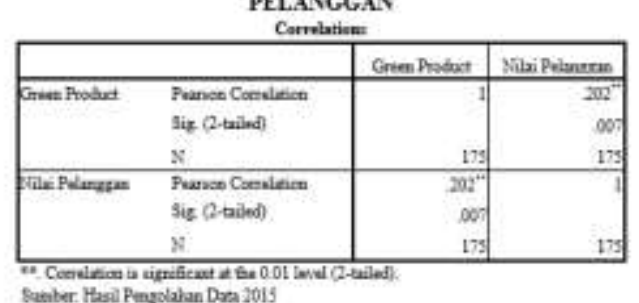

Berdasarkan tabel 4.3 dapat diketahui bahwa nilai pearson correlation adalah sebesar 0,202 artinya green product berpengaruh rendah terhadap nilai pelanggan berdasarkan interpretasi koefisien korelasi nilai $r$ (0,20$0,399)$. Nilai siginifikansi $0,007<0,05$ level of significant $(\alpha)$ berarti Ho ditolak. Artinya, green product berkorelasi dengan nilai pelanggan. Jika semakin meningkat green product maka nilai pelanggan pun akan semakin meningkat, dan sebaliknya jika green product semakin menurun maka nilai pelanggan akan menurun juga.

d. Koefisien Determinasi

Persentase pengaruh semua variabel independen atas variabel dependen ditunjukkan oleh besarnya koefisien determinasi. Besarnya nilai koefisien determinasi dapat dijelaskan pada berikut: TABEL 4.4

HASIL UJ KOEFISIEN DETERMIINASI GREEN PRODUCT IERHADAP NILAI PELANGGAN

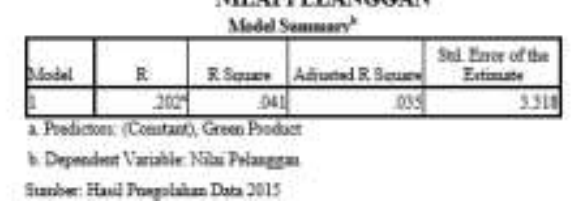


Berdasarkan tabel 4.4 di atas, diperoleh nilai RSquare sebesar 0,041 atau 4,1\%. Hal ini menunjukkan bahwa variabel bebas yang merupakan green product (X) memberikan kontribusi atau pengaruh sebesar 4,1\% terhadap nilai pelanggan pada pengguna Sariayu di Yogya Kepatihan Bandung dan sisanya sebesar 95,9\% dipengaruhi oleh faktorfaktor lain diluar penelitian.

Koefisien determinasi sebesar 4,1\%, artinya nilai pelanggan yang dapat dipengaruhi oleh program green product $(\mathrm{X})$ oleh persamaan regresi $Y=16,788+0,163 X$ adalah sebesar 4,1\%, sisanya sebesar 95,9\% dipengaruhi faktor lain.

\section{Pengaruh Nilai Pelanggan Terhadap Repurchase Intention}

\section{a. Uji Normalitas}

Untuk menguji normalitas data, penelitian ini menggunakan Normal Probability Plot seperti pada gambar 4.2 berikut.

Normal P.P Plot of Regression Standardized Residual

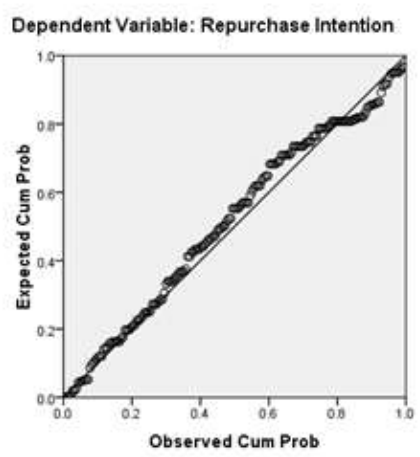

GAMBAR 4.2

DIAGRAM GARIS NORMAL P-PLOT NILAI PELANGGAN TERHADAP REPURCHASE INTENTION PADA PENGGUNA SARIAYU DI YOGYA KEPATIHAN BANDUNG

Berdasarkan Gambar 4.2 dapat disimpulkan bahwa model regresi yang diperoleh berdistribusi normal, dimana titik-titik sebaran data mengikuti garis lurus dan menyebar disekitar garis diagonal tersebut.

b. Uji Regresi Linier Sederhana

Regresi digunakan untuk mengetahui seberapa besar pengaruh nilai pelanggan terhadap repurchase intention, output ANOVA terdapat pada tabel 4.5 .

TABEL 4.5

OUTPUT ANOVA NIL.AI PEI ANGGAN TERHADAP REPURCHASE LNTENTION

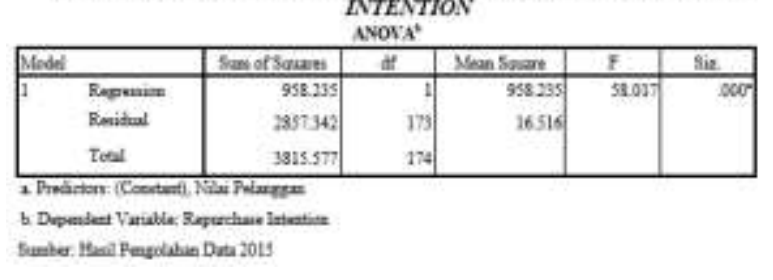

Berdasarkan Tabel 4.5 ANOVA, dapat diketahui besar $\mathrm{F}$ hitung adalah 58,017 sedangkan $\mathrm{F}$ tabel adalah 3,048, karena nilai $F_{\text {hitung }}>F_{\text {tabel, }}$ yaitu $58,017>3,89$ juga nilai signifikansi sebesar 0,000<0,05 (taraf signifikansi 5\%) maka dapat disimpulkan Ho ditolak, yang artinya terdapat hubungan linier antara nilai pelanggan dengan repurchase intention.

TABEL 4.6
OUTPUT KOEFISIEN REGRESI NIL.AI PELANGGAN TERHADAP REPLRCH ASE INTENTION

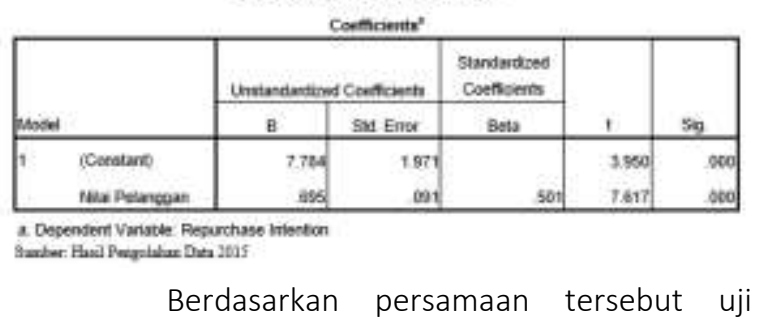
regresi linier sederhana dapat dijelaskan sebagai berikut:

1. Koefisien konstanta sebesar 7,784 menunjukkan apabila nilai pelanggan bernilai 0 (nol) maka nilai pelanggan bernilai 7,784.

2. Setiap peningkatan skor sebesar satu satuan nilai pelanggan, maka akan berdampak pada kenaikan nilai repurchase intention sebesar 0,695.

Berdasarkan tabel 4.6 juga dapat diketahui besarnya t-hitung yaitu sebesar 7,617 sedangkan besarnya t-tabel 1,97 atau t-hitung > t-tabel yaitu 7,617>1,97 maka dapat disimpulkan Ho ditolak, artinya ada hubungan linier antara nilai pelanggan dengan repurchase intention dengan tingkat signifikansi sebesar 0,000 yang lebih kecil dari taraf signifikansi 0,05 (5\%). 
c. Analisis Koefisien Korelasi

Untuk mengetahui derajat hubungan anatara nilai pelanggan dengan repurchase intention dan untuk mengetahui arah serta kuatnya hubungan antara kedua variabel tersebut, maka digunakan tabel 4.7 koefisien korelasi seperti berikut:

\section{TABEL 4.7 \\ OUTPUT KOEFISIEN KORELAST NILAI PELANGGAN TERHADAP} REPURCHASE LNTENTION

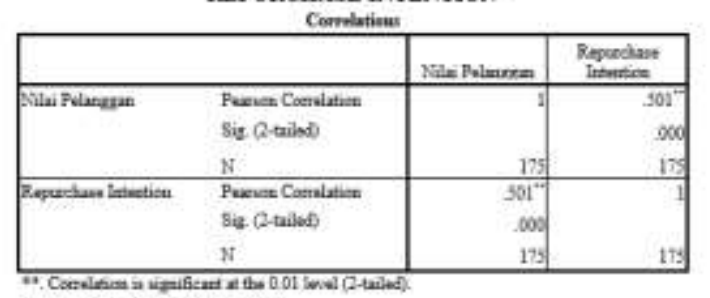

Sunter. Fanil Pengelahum Dah 2015

Berdasarkan tabel 4.7 dapat diketahui bahwa nilai pearson correlation adalah sebesar 0,501 artinya nilai pelanggan berpengaruh sedang terhadap repurchase intention berdasarkan interpretasi koefisien korelasi nilai $r \quad(0,40$ 0,599). Nilai siginifikansi $0,000<0,05$ level of significant $(\alpha)$ berarti Ho ditolak. Artinya, nilai pelanggan berkorelasi dengan repurchase intention. Jika semakin meningkat nilai pelanggan maka repurchase intention pun akan semakin meningkat, dan sebaliknya jika nilai pelanggan semakin menurun maka repurchase intention akan menurun juga.

d. Koefisien Determinasi

Besarnya nilai koefisien determinasi dapat dijelaskan pada berikut:

TABEL 4.8

HASIL UII KOEFISIEN DETERMIINASI NIL.AI PELANGGAN IERHADAP REPTRCHASE INTENTION

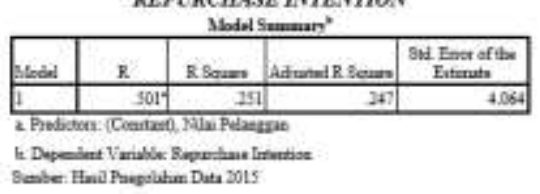

Berdasarkan tabel 4.8 di atas, diperoleh nilai RSquare sebesar 0,251 atau 25,1\%. Hal ini menunjukkan bahwa variabel bebas yang merupakan nilai pelanggan (X) memberikan kontribusi atau pengaruh sebesar 25,1\% terhadap repurchase intention pada pengguna Sariayu di Yogya Kepatihan Bandung dan sisanya sebesar 74,9\% dipengaruhi oleh faktorfaktor lain diluar penelitian.

Koefisien determinasi sebesar 25,1\%, artinya nilai pelanggan yang dapat dipengaruhi oleh program green product $(X)$ oleh persamaan regresi $Y=7,784+0,695 X$ adalah sebesar 25,1\%, sisanya sebesar $74,9 \%$ dipengaruhi faktor lain.

\section{Pengaruh Green Marketing Terhadap Repurchase Intention}

a. Uji Normalitas

Untuk menguji normalitas data, penelitian ini menggunakan Normal Probability Plot seperti pada gambar 4.3 berikut.

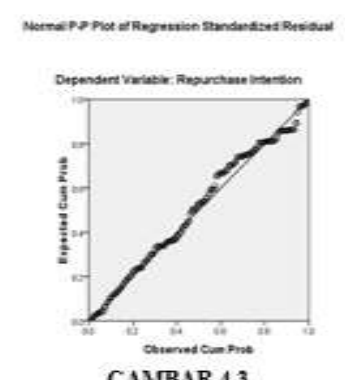

DIAGRAM GARIS NORMLAL P-PLOT GREEN PRODUCT TERHADAP REPCRCHASE INTENTION PADA PENGGUNA SARIAYU DI YOGYA KEPATIHAN BANDUNG

Berdasarkan Gambar 4.3 dapat disimpulkan bahwa model regresi yang diperoleh berdistribusi normal, dimana titik-titik sebaran data mengikuti garis lurus dan menyebar disekitar garis diagonal tersebut.

b. Uji Regresi Linier Sederhana

Regresi digunakan untuk mengetahui seberapa besar pengaruh green product terhadap repurchase intention, output ANOVA terdapat pada tabel 4.9.

TABEL 4.9
OUTPUT ANOVA GREEN PRODLCT TERHADAP REPLRCH 4 SE INTENTION

\begin{tabular}{|c|c|c|c|c|c|c|}
\hline \multicolumn{7}{|c|}{ ANOVAN" } \\
\hline Mode & & Sum of Sovares & dif & Mean Squave & $F$ & $S_{9}$ \\
\hline \multirow[t]{3}{*}{1} & Regression & 24,107 & 1] & 24.107 & 1.100 & $296^{\circ}$ \\
\hline & Residual & 3791.470 & 173 & 21916 & & \\
\hline & Total & 3915.577 & 174 & & & \\
\hline
\end{tabular}

a. Predidiors (Constamti, Geeen Prosuct

b. Desendert Variabie. Repurchase intertion

Sumber: Hawl Pery lahan Data 2015

Berdasarkan Tabel 4.9 ANOVA, dapat diketahui besar $F$ hitung adalah 1,100 sedangkan $F$ tabel adalah 3,048, karena nilai $F_{\text {hitung }}<F_{\text {tabel, }}$ yaitu $1,100<3,89$ juga nilai signifikansi sebesar 
0,296>0,05 (taraf signifikansi 5\%) maka dapat disimpulkan Ho diterimaa, yang artinya tidak terdapat hubungan linier antara green product dengan repurchase intention.

TABEL 4.10

OUTPUT KOEFISIEN RECRESI GREEN PRODLCT TERHUDAP REPCRCHASE LNTENTION

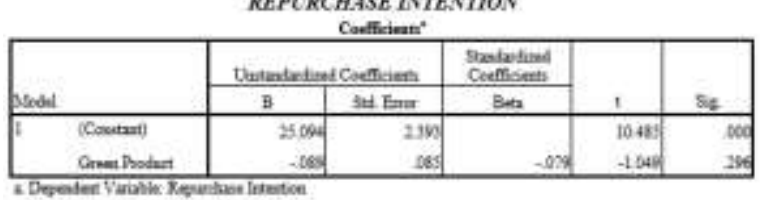

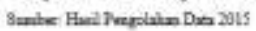

Berdasarkan persamaan tersebut uji regresi linier sederhana dapat dijelaskan sebagai berikut:

1. Koefisien konstanta sebesar 25,094 menunjukkan apabila green product bernilai 0 (nol) maka repurchase intention bernilai 25,094.

2. Setiap peningkatan skor sebesar satu satuan green product, maka akan berdampak pada penurunan nilai repurchase intention sebesar 0,089.

Berdasarkan tabel 4.10 juga dapat diketahui besarnya t-hitung yaitu sebesar $(-1,049)$ sedangkan besarnya t-tabel 1,97 atau t-hitung < t-tabel yaitu $-1,049<1,97$ maka dapat disimpulkan Ho diterima, artinya tidak ada hubungan linier antara green product dengan repurchase intention dengan tingkat signifikansi sebesar 0, 296 yang lebih besar dari taraf signifikansi 0,05 (5\%).

\section{c. Analisis Koefisien Korelasi}

Untuk mengetahui derajat hubungan anatara green product dengan repurchase intentiondan untuk mengetahui arah serta kuatnya hubungan antara kedua variabel tersebut, maka digunakan tabel 4.11 koefisien korelasi seperti berikut:

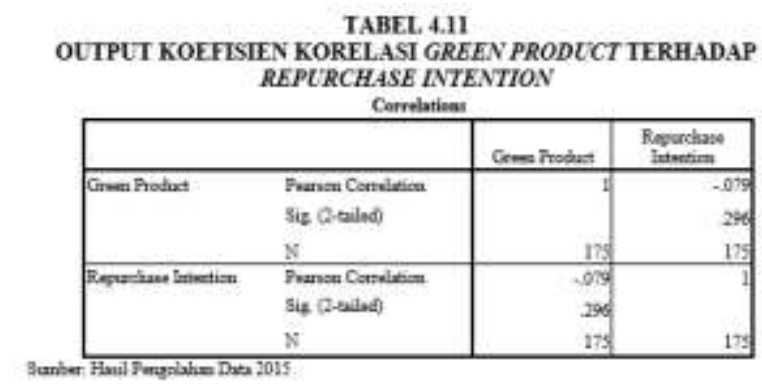

Berdasarkan tabel 4.11 dapat diketahui bahwa nilai pearson correlation adalah sebesar $-0,079$ artinya green product tidak berpengaruh terhadap repurchase intention. Nilai siginifikansi $0,296>0,05$ level of significant $(\alpha)$ berarti Ho diterima. Artinya, green product tidak berkorelasi dengan repurcase intention. Karena hasil menunjukan bahwa green product tidak berpengaruh terhadap repurchase intention maka tidak dilakukan uji koefisien determinasi.

4. Pembahasan Hasil Penelitian

Berdasarkan hasil perhitungan koefisien path yang dinyatakan oleh nilai beta pada output coefficients dalam perhitungan menggunakan SPSS 16.0 terlihat bahwa pengaruh green product terhadap nilai pelanggan memiliki pengaruh signifikan sebesar $4,1 \%$.

Hasil analisis pengaruh nilai pelanggan terhadap repurchase intention menunjukan hasil yang signifikan dengan besar pengaruh 25,1\%, artinya nilai pelanggan berpengaruh signifikan dan positif terhadap repurchase intention, ketika nilai pelanggan mengalami peningkatan satu satuan maka akan berpengaruh terhadap peningkatan repurchase intntion sebesar $25,1 \%$.

Hasil analisis untuk pengaruh green product terhadap repurchase intention memiliki nilai signifikansi sebesar 0,296 lebih besar dari taraf signifikansi sebesar 0,05, yang artinya tidak terdapat pengaruh green product terhadap repurchase intention. Hal tersebut mungkin dikarenakan responden sebagian besar belum memahami benar mengenai konsep green product.

Konsep green product yang dilakukan untuk memberikan nilai lebih terhadap produk yang ditawarkan untuk konsumen, namun ketika konsumen 
tidak memahami apa yang dimaksudkan oleh produsen hasilnya nilai lebih yang ditawarkan menjadi tidak dapat diterima oleh konsumen, sehingga perlu komunikasi yang baik agar upaya Sariayu dalam konsistensinya memproduksi produk alami (green product) dapat dipahami oleh konsumen dan menjadikan faktor besar untuk menarik konsumen kembali menggunakan produk Sariayu.

\section{KESIMPULAN}

Berdasarkan penelitian dan pembahasan pada bab sebelumnya maka dapat ditarik kesimpulan sebagai berikut:

1. Green product diterima baik oleh konsumen Sariayu Martha Tilaar di Yogya Department Store Jalan Kepatihan Bandung. Gambaran green product yang dilakukan Sariayu dapat dilihat dari dimensidimensinya yang terdiri dari energy based product, material driven product, pollution prevention product dan packaging. Pollution prevention product memiliki nilai paling tinggi. Hal ini menunjukan bahwa meningkatnya kesadaran konsumen terhadap lingkungan membuat permintaan terhadap produk alami (green product) meningkat, dan Sariayu Martha Tilaar merupakan salah satu perusahaan yang konsisten untuk menciptakan produk alami yang aman bagi pengguna dan alam.

2. Nilai pelanggan dipersepsikan baik oleh konsumen Sariayu Martha Tilaar di Yogya Department Store Jalan Kepatihan Bandung. Gambaran dari nilai pelanggan dapat dijelaskan melalui rational value dan emotional value. Nilai tertinggi ada pada dimensi rational value. Artinya bahwa konsumen yang memutuskan untuk menggunakan produk Sariayu lebih mempertimbangkan manfaat secara nyata dari sebuah produk. Konsumen menggunakan Sariayu dengan harapan mendapatkan manfaat bagi kesehatan kulit serta mempercantik penampilan.

3. Repurchase intention dilakukan cukup baik oleh konsumen Sariayu Martha Tilaar di Yogya Department Store Jalan Kepatihan Bandung. Gambaran mengenai repurchase intention dilihat dari tingkat intensitas pembelian, kuantitas pembelian dan minat meneruskan pembelian ulang. Intensitas pembelian memiliki nilai paling tinggi. Konsumen merasa memerlukan dan sudah bergantung pada produk Sariayu. Melakukan frekuensi pembelian cukup sering serta mementingkan keberadaan produk atas diri mereka.

4. Semakin tinggi keunggulan green product akan semakin tinggi juga nilai pelanggan yang dirasakan konsumen. Maka dari itu Green product berpengaruh positif terhadap nilai pelanggan dengan korelasi sangat rendah.

5. Semakin tinggi nilai pelanggan yang dirasakan akan semakin tinggi juga repurchase intention yang dilakukan konsumen. Maka dari itu nilai pelanggan berpengaruh positif terhadap repurchase intention dengan korelasi rendah.

6. Green product tidak memiliki pengaruh langsung terhadap repurchase intention. Hal tersebut dikarenakan green product cenderung rendah sedangkan repurchase intention cenderung tinggi.

\section{REKOMENDASI}

Sariayu yang selalu konsisten menciptakan nature care product, berbahan dasar alami serta menggunakan kekayaan budaya indonesia bagi rangkaian produknya telah menjadikan Sariayu menjadi green company. Produk alami memang sudah melekat pada produk Sariayu, namun konsep yang teah diterapkan ini masih memiliki kekurangan. Konsumen masih kurang memahami konsep green product yang diterapkan oleh Sariayu. Masih perlu diberikan komunikasi pemasaran yang baik agar konsumen dapat memahami secara menyeluruh mengenai konsep green product yang ditawarkan oleh Sariayu.

Berdasarkan hasil penelitian nilai pelanggan memiliki kontribusi paling besar dalam mempengaruhi konsumen melakukan pembelian ulang. Sariayu dirasa perlu menawarkan lebih banyak varian produk yang dapat memberikan nilai lebih bagi konsumen. Saat ini tidak hanya kaum wanita yang mulai memperhatikan penampilan atau membutuhkan produk perawatan, kini kaum pria juga sudah peduli dengan kesehatan kulit serta penampilan mereka. Untuk melihat peluang 
pasar ini, Sariayu sebaiknya bisa menciptakan pilihan produk untuk kaum pria, sehingga memperluas pasar.

Green product yang belum memiliki pengaruh langsung terhadap repurchase intention diharapkan dapat diperbaiki oleh Sariayu dalam memperkuat konsep serta komunikasi dalam pemasarannya, seperti melakukan sosialisasi kepada masyarakat melalui iklan di media televisi, mengadakan acara beauty class maupun sosial media yang saat ini sedang marak digunakan. Agar upaya yang selama ini dilakukan dapat meningkatkan dan mempertahankan loyalitas pelanggan yang pada akhirnya akan meningkatkan penjualan perusahaan.

Hasil penelitian yang menunjukan bahwa tidak terdapat pengaruh langsung mengenai green product terhadap repurchase intention diharapkan dapat dijadikan acuan bagi peneliti selanjutnya untuk dapat melakukan penelitian mengenai green product dengan objek dan indikator berbeda, atau meneliti repurchase intention dengan variabel bebas lain seperti perceived quality, word of mouth endorsement, experience marketing, dan lainnya.

Nilai pelanggan diharapkan dapat ditingkatkan terus oleh Sariayu, karena nilai pelanggan merupakan faktor terbesar dalam penelitian ini untuk meningkatkan minat pembelian kembali konsumen terhadap produk Sariayu.

\section{DAFTAR PUSTAKA}

Akdeniz, A. Effect of Perceived Values on The Brand Preference and The Purchase Intention. European Scientific Journal, August edition vol. 8, No.17 ISSN: 1857 - 7881 (Print) e - ISSN 1857- 7431.

Chen, C. Y., \& KaoY. C. (2005). Development and Analysis of a Framework for

Evaluating a Green Production and Consumption System. Journal of Humanities and Social Sciences, 1(1), 1-17.

Choi, E.J., and Soo-Hyun Kim. (2013). The Study of the Impact ofPerceived

Quality and Value of Social Enterprises on Customer Satisfaction and RePurchase
Intention.International Journal of Smart Home Vol. 7, No. 1.

Kotler, P., dan Kevin L.K. (2012). Marketing Management (Edisi 14e). New Jersey: Pearson Education.

Kotler, P., dan Gary A. (2012). Prinsip-prinsip Pemasaran (Edisi 13). Jilid 1. Jakarta: Erlangga.

Maheshwari, Shruti P. (2014). Awareness of Green Marketing and its Influence on Buying Behavior of Consumers: Special Reference to Madhya Pradesh, India. AIMA Journal of Management \& Research, Volume 8 Issue 1/4, ISSN 0974 - 497.

Hurriyati, Ratih., (2010). Bauran Pemasaran dan Loyalitas Konsumen: Fokus pada Konsumen Kartu Kredit Perbankan, Bandung: Alfabeta.

Sugiyono. (2014). Metode Penelitian Kuantitatif, Kualitatifdan R\&D. Bandung: Alfabeta. Sugiyono. (2014). Statistika untuk Penelitian. Bandung: Alfabeta.

Sugiyono. (2010). Metode Penelitian Bisnis, Bandung: Alfabeta.

Teunter, Linda H. (2002). "Analysis of Sales Promotion Effect on Houshold Purcahse Behaviour". Rotterdam: Journal of the Erasmus Research Institute of Management (ERIM).

http://indonesianconsume.blogspot.com/

http://www.swa.co.id/business-research/bcgpertumbuhan-kelas-menengahindonesia-meluaske-daerah

http://mobile.kontan.co.id/news/pasar-kosmetiknasional-naik-15-di-2014

http://m.metrotvnews.com/read/2014/08/26/282964 /produk-kosmetik-dan-jamuharus-menang-didalam-negeri

www.infofesta.com

http://www.martinaberto.co.id/investor.php?page=in vestor_financial_reports

http://swa.co.id/business-strategy/jurus-wardahgarap-pasar-kosmetik

http://m.inilah.com/news/detail/1935707/mbtotargetkan-penjualan-tumbuh-88-di2013

http://www.martinaberto.co.id/default.php?page=ma rtinaberto\&id=37\&lang=id 
